\title{
ARAB CONTRIBUTIONS TO HYDRONYMY: THE DETECTING OF UNDERGROUND WATER THAT LED TO THE CONSTRUCTION OF WATER WELLS
}

\author{
ALI BAKR HASSAN \\ Effat University, Jeddah, Saudi Arabia
}

\begin{abstract}
This paper focuses on Arab contributions to agricultural heritage in early Islam. It explores their knowledge and use of certain plants and rocks as methods of detecting underground water, which ultimately led to the construction of water wells and irrigation systems. Arabs called this kind of knowledge 'Ilm al-Riyâfah. "Hydronymy" would be the closest term to this kind of knowledge in the West. In the absence of modern technology, these older methods for detecting underground water are still highly practical and useful today - especially in desert areas. Arabs used some signs as indicators for underground water. In the mountains, they depended on the color of certain spots. In the valleys, there were some human experts to guide people where to dig for water. In the desert, Arabs relied on plants. They recorded these plants and used them as indicators to dig for water. A compiled list of these plants, along with their images, scientific names, and brief descriptions, is provided. These plants have some interesting commonalities. The roots of some plant species, for example can extend as far as fifty meters below the surface trying to reach hidden water. Also, some of these plants are thorny, distasteful, or toxic. These capabilities allowed them to persist and survive, despite harsh conditions, droughts, and famine. Many of these plants were used for traditional medicine as they have been prescribed by Avicenna, Rhazes and Ibn al-Baytâr. This study explores another usage of these plants, which is detecting underground water.

Keywords: Bi'r, water wells, underground waters, Arab usage of plants and conduits, Arabs and hydronomy, Arabs' contributions to hydrology.
\end{abstract}

\section{INTRODUCTION}

Water sources, water wells, and irrigation systems are a subject area of knowledge that Arabs refer to as ' $I l m$ al-Riyâfah, which the study that early Arabs were able to develop to address subterranean waters. One of its objectives was to improve water scarcity and security by ways of decentralization. (The closest parallel discipline in the Western world could be hydronymy - names of bodies of water.) The importance of and need for water is universal. In the desert areas, such as in Arabia, water is hugely important for irrigation-related purposes establishing farms, and maintaining livestock. Drinking from the Well of Zamzam in Mecca is one of the Muslim rituals in performing Hajj, the fifth pillar of Islam.

Arabs were able to connect plants with detecting underground water. Historically, it is well known that early Arab scholars made a good use of plants in the field of medicine. The physician Avicenna (Ibn Sînâ), his work The Canon in Medicine, Rhazes (al-Râzî), his work Ma-la-yahduruhu al-tabîb (what to do in the absence of the physician) and Ibn al-Baytâr, his work Kitâb al-Jâmic li-Mufradât al-Adwiyah wa-l-Aghdhiyah, (Compendium on Simple Medicaments and Foods) just to name a few, are among Muslim scholars who left major works in the field of medicine, pharmacology, and botany consecutively. However, what is not as well known is that Arabs also used plants for the purpose of detecting underground water, with a special emphasis on creating water wells and irrigation systems. Although the ancient methods for detecting underground water may be viewed today as primitive when compared to modern technology, in the absence of that technology, these old methods are still highly practical and useful - especially in desert areas. 
Studying the Arab contributions in detecting hidden water is of great significance. In the Middle ages, Arabs developed different methods in detecting and extracting water. In addition, this paper examines the ability of the Arabs in discovering the places where water existed, and measuring how far deep water was, so that they can determine where they can start drilling. They called these techniques ${ }^{C}$ Ilm al-Riyâfah. Finally, the shortage of water at the present time is a worldwide problem; thus, I profoundly believe that any attempt of reconstructing part from the past may contribute to finding a solution to a problem of our present. For example, the rise of present-day cities especially in Middle East, Africa and other areas often brings waves of drought and famine, so it requires increasingly sophisticated methods of water discovery to supply rapidly growing populations by helping their land to flourish and enabling these populations to attain order in their daily lives. In the absence of the most sophisticated equipment with water sensors, the Arab methods of knowing how to discover underground water would be of great significance.

\section{EARLY DETECTION METHODS OF HIDDEN WATER}

In early Islam, Arabs used plants as signs or indicators for finding underground water so that they would know where is the best place to dig. Some common factors among these plants were long roots, which went deep into the ground; some plants were also distasteful or toxic, which helped them to survive despite harsh conditions, drought, and famine. On mountains, Arabs would look for rocks with certain colors or spots. The type of mountaintop also was a consideration; wider mountaintops usually contained more water than other types of mountains. For example, while water could be easily detected in black and green mountains, water was rarely found in yellow or red mountains. In addition, huge amounts of water were found in a chain of mountains, which contained depressions. Arabs realized that the water's existence was due to falling snow, which was absorbed by the depressions and then preserved from heat and evaporation.

In the valleys, Arabs would rely on human experts to guide and direct people where to dig for water. These experts were called Qanâqin (sing. Qinqin) and they still exist today. Qinqin is a Persian term for people who are in the profession of detecting hidden water. (The closest Western terms to the Qinqin profession are hydrologists, geologists, or hydronymy specialists.) While the Qinqin term is used in the Eastern part of present-day Iran, other terms that are more common among Arabs include al-c'Assâs (pl. ' ${ }^{c}$ Assâsah or ${ }^{c}$ Assâsûn), al-Mubassir, or al-Murrî, which are all used in present-day Arabia.

Qinqin experts did not study the art of detecting hidden water in any kind of school. In the process of looking for underground water, the Qinqin and ${ }^{c}$ Assâs often held a small iron bar in their hands as they search for water. (Dowsers in the Western world similarly used a metal dowsing bars or rods [also called "diving rod"] that would spontaneously or suddenly jerk downward if a water source was present.) However, it is unknown how helpful these dowsing bars or rods actually were (or still are) in detecting hidden water.

In the desert, where water is needed most, detailed knowledge about the land was needed for detecting underground water. Arabs knew that the ability to detect water depends upon the topographical nature of the area. Valleys, for example, have different indicators (soil) from mountains (rocks). Abû Bakr al-Karajî details these observations stating that if stones were soft and black in sandy areas, one could expect that there was hidden water. Lands that are adjacent to mountains are more likely to have water, even if it seems arid. The amount of water available also gradually decreases as the location is further away from the mountain (see al-Karajî [9, p. 39]).

Another method for detecting hidden water was Arabs' observation of certain meteorological phenomena in the early morning. When they saw some kinds of plants 
covered with dew or moisture in the early morning, they believed that the dew was an indication of underground water that was close to the surface. Foggy and hazy areas were more likely to have underground water if the area consisted of black clay or if the land was well cultivated, an aquifer (a water-bearing stratum of permeable rock, sand, or gravel) would be in this area and could be reached easily (see al-Karajî [9, p. 40]). Collectively, these individual pieces of knowledge helped Arabs and the Qnâqin locate good water resources.

\section{THE WELL ( $\left.A L-B^{\prime} I R\right)$ : A LITERATURE REVIEW}

In Arabia, Wells were a main source of water for people, cattle, and agricultural irrigation, as well as other purposes. Some early wealthy Arabs exerted their utmost efforts to create sustainable water supplies. It was a turning point in the early history of Muslims in al-Madinah when ' ${ }^{\mathrm{C}}$ thmân ibn ${ }^{\mathrm{c}}$ Affân (d. 35 AH/656 AD) purchased the Well of Rûmah. Later, Zubaydah (d. 216/831), the wife of the 'A Abbasid Caliph Hârûn al-Rashîd (d. 193/809), endowed some of her wealth to dig water wells all along Zubaydah Trail Darb Zubaydah, which stretches from Baghdad to Mecca. One of these wells is called Bi'r Zubâlah, is 250 meters deep (approx. 820 feet). The main purpose of this well was to supply the pilgrims with their water needs. Although the road no longer exists, the well does.

Additionally, throughout Arabia, wherever was a water well, an Arab society was established. Sometimes wars among Arab tribes erupted solely because of a well. Arabs also gave different names to different wells depending on their size and type. The Quran gives two names for the word "well": jubb (Quran, 12/10), and bi'r (Quran, 22/45). Therefore, it is worthwhile to study the subject of water wells and how Arabs, in early Islam, were able to find underground sources of waters, how they measured how far and how deep the water runs and how they created wells and irrigation system.

In early Islam, although water wells were of great significance, not much has been written about them. Ibn al-A'râbî (d. 231 AH/844 AD) dedicated his work, The Book of Well (kitâb $a l-b i$ 'r) and identified many wells. He collected many names and arranged them in a way that is similar to a dictionary. Each well derived its name from its features, such as width, depth, taste of water, or amount of water that the well could produce. As a linguist, however, he listed all the well names in Arabic with a brief description that followed. His compiled list of wells exceeds fifty names and a similar number of descriptions. In addition, Ibn al- $A^{c}$ rabî's work is the only one that focuses its entirety on wells. Ibn Wahshiyah (d. 269 AH/909 AD) authored 'Ilal al-miyâh, and al-Karajî authored Inmât al-miyâh al-khafiyah; both can be counted as works about hydrology. Despite the fact that Ibn al-Acrâbi dedicated his entire book to the well (al-bi'ir), he failed to give a clear definition of it.

Erich Brauslich defines the well as a construction built into the earth to afford an outlet for subterranean waters (Brauslich [5, v. 1, p. 464]). It is interesting that Brauslich explicitly mentioned "construction", a term that is almost absent in the Arabic dictionaries, which mostly refer to wells as holes in the ground with bubbles that form in water. The term bi'r is commonly known as water that collects, rises, and breaks forth.

It is rather surprising, and contrary to many fields, to find few works in Arabic literature that address the process of constructing water wells despite the important role that these wells played in the life of early Arabs. So far, we know of only a few treatises that touch upon the subject of wells. It seems that Arabs were more practical in drilling and getting the work done rather than writing about these processes that took place. Another reason for the sparsity of Arabic literature is that those who were knowledgeable about wells were farmers who were not well educated or experienced in research and writing. The few ${ }^{c}$ ulama who wrote about the subject had their works produced as simple treatises. However, when collecting pieces 
and parts from these early works, one can reconstruct pictures about water wells and their construction that could be close to the original ones.

Among these treaties is Inmât al-miyâh al-khafiyah (The extraction of the hidden waters) of Abû Bakr Muhammad ibn al-Hassan al-Karajî (d. 410/1019). This work is a seminal technical manual-like in the subject of how to locate the hidden waters, how to drill wells, and how to extract water by building underground aqueducts (qinî sing. qanât). Although al-Karajî is well known as a mathematician, particularly to the field of algebraic calculus, he employed his geometric talent toward his hydrological burning curiosity, which puts his work as being the oldest text in the hydro-geomatical field. Al-Karajî lived for some time in a mountainous area called Ard al-Jabal (the land of mountain), part of the ancient Persian empire, in what is now Iran. Many assumed that this area was Karaj, which Abû Bakr had attributed to al-Karajî, so al-Karajî then became known. This area is located between four mountains full of farms and villages, as well as several rivers and water sources. There, al-Karajî developed his hydraulic projects for empirical research, which focused on how to build underground conduits for vital social usage and agricultural economic benefits by providing water in arid places. These projects laid the ground not only for the people of Ard al-Jabal but also for anywhere else in the world with topographical similarities and water scarcity.

\section{TECHNIQUES AND TOOLS}

During the course of his research, al-Karajî developed some instruments, such as calibrated plate for surveying and its chains and staves as well as description of a diopter-like instrument of today (al-Karajî, 1359 AH, pp. 39-56), which enabled him to achieve his task. From the descriptions detailed toward the end of his treaties, al-Karajî, describes his instruments. From the detailed descriptions, one can conclude that his instruments were similar to those used today.

Relying on the hydrologic knowledge, which al-Karajî acquired from ancient Persia and in his own research, al-Karajî reveals a profound and exacting technical understanding of groundwater theory. As such, his contributions in this field is the oldest known text on the subject. His knowledge of the hydrological cycle matches our concept of the same cycle of the present time. By having done so, he is proven to be a master of hydrology in early Islam, and he was familiar with the basic hydrologic, geologic, and engineering principles associated with groundwater, as known today (Abattouy).

It is interesting to notice that when Arabs were looking for a location where they can drill for water, the depth was not their major concern. Rather, it was the sustainability of the water. They preferred to dig deeper into the ground to obtain a considerably larger amount of gathering water rather than to dig a shallow amount into the ground, which would dry out quickly as soon as they start drainage. A good example of this desire to dig deep is the well of Zubâlah. In this well, as they dug deeper, more underground canals (aflâj sing. falaj), that met each other until they became a source of bountiful water.

The digging and operation of a well presupposes several technological and socio-economic conditions: procuring or designing tools to dig out or to break through the soil and rocks; and material to help support the walls of the well. Often, a well is the beginning of a human settlement because the digging of a well requires general solidarity among the people, especially in the wilderness.

Using conduits for irrigation (a system that possibly originated from ancient Persia) became one of the most effective methods for providing water in regions without perennial streams. However, early Muslims were able to further develop this system and use it to supply water over a long distance. This irrigation system was widespread in the Muslim land, such 
as Khurasân, Mecca, Cairo and many areas in Oman and Yemen. During the rain of the ${ }^{\mathrm{c}}$ Abbasid Caliph al-Mutawakkil (847-866 AD), there was a conduit of 300 miles in length. It stretched from the upper Tigris River to the Caliph's palace, in the city of Samarra (see Abattouy [1]). Al-Karajî provides great details of constructing the conduits, the best time of the year to do so, conduit lining, their protection against rust and decay, and their maintenance against the collection of clay and the growing algae (al-Karajî [9, pp. 57-63]).

\section{PLANTS USED AS INDICATORS FOR HIDDEN WATER}

In early Islam, it was not unusual for the Arabs to detect underground water by observing the types of huckleberry, which grew naturally in the wilderness, and recording some of these floras and plants. Arabs' naming these plants based mostly on the plants' descriptions and specifications. Table 1 consists of the most common plants that were recorded by early Arab botanists and hydrological engineers.

Table 1: A list of plants used as indicators for hidden waters.

\begin{tabular}{|c|c|c|}
\hline Scientific name & $\begin{array}{l}\text { Transliterated names (see this } \\
\text { list in al-Karajî [9, p. 42]) }\end{array}$ & Images \\
\hline $\begin{array}{l}\text { Portulaca } \\
\text { oleracea }\end{array}$ & $\begin{array}{l}\text { al-Baqlah al-hamqâ': } \\
\text { Its deep roots bring up moisture } \\
\text { and nutrients that those plants } \\
\text { can use, and some, including } \\
\text { corn, will follow Purslane roots } \\
\text { down through harder soil that } \\
\text { they cannot penetrate on their } \\
\text { own. } \\
\text { (Ibn Sînâ [14, p. 239], Yan-Xi } \\
{[18, \text { id \#925631]). }}\end{array}$ & \\
\hline Cyperus papyrus & $\begin{array}{l}\text { al-Bardî: } \\
\text { In Ancient Egypt, papyrus was } \\
\text { used for various of purposes } \\
\text { such as baskets, sandals, } \\
\text { blankets, medicine, incense, and } \\
\text { boats. The woody root was used } \\
\text { to make bowls and utensils and } \\
\text { was burned for fuel. } \\
\text { (Ibn Sinâ [14, p. 148], Bedevian } \\
\text { [4, p. 223]). }\end{array}$ & \\
\hline $\begin{array}{l}\text { Ribes uva-crispa } \\
\text { Another name: } \\
\text { Ribes grossularia }\end{array}$ & $\begin{array}{l}{ }^{\mathrm{c} I n a b} \text { al-Thaclab: } \\
\text { It is also known as gooseberry. } \\
\text { Gooseberry bushes produce an } \\
\text { edible fruit and are grown on } \\
\text { both a commercial and domestic } \\
\text { basis (Bedevian [4, p. 440]). }\end{array}$ & \\
\hline
\end{tabular}


Table 1: Continued.

\begin{tabular}{|c|c|c|}
\hline Scientific name & $\begin{array}{l}\text { Transliterated names (see this list } \\
\text { in al-Karajî }[9, \text { p. } 42] \text { ) }\end{array}$ & Images \\
\hline $\begin{array}{l}\text { Mantha another } \\
\text { name: Ocimum }\end{array}$ & $\begin{array}{l}\text { al-Habaq al-Nahrî: } \\
\text { It is perennial herbs. They have } \\
\text { wide-spreading underground and } \\
\text { over-ground stolons and erect, } \\
\text { square, branched stems. The } \\
\text { species that make up the genus } \\
\text { Mentha are widely distributed } \\
\text { and can be found in many } \\
\text { environments. Most grow best in } \\
\text { wet environments and moist soils. } \\
\text { It is also called in English wild } \\
\text { mint or horse mint (Ibn Sinâ [14, } \\
\text { p. } 215] \text {, Bedevian [4, p. } 393]) \text {. }\end{array}$ & \\
\hline $\begin{array}{l}\text { Rumex } \\
\text { obtusifolius also } \\
\text { Rumex acetosa }\end{array}$ & $\begin{array}{l}\text { al-Hummâd: } \\
\text { It is a perennial herbaceous } \\
\text { flowering plant that grows to a } \\
\text { height of } 50 \text { to } 130 \mathrm{~cm} \text { ( } 20 \text { to } 51 \\
\text { in). It is easily recognizable by its } \\
\text { very large oval leaves with } \\
\text { cordate bases and rounded tips, } \\
\text { some of the lower leaves having } \\
\text { red stems (see Bedevian [4, pp. } \\
516-517]) \text {. }\end{array}$ & \\
\hline Lycium shawii & $\begin{array}{l}\text { al-c Awsaj: } \\
\text { It is also known as desert thorn or } \\
\text { Arabian boxthorn, is a species of } \\
\text { thorny shrub adapted to desert } \\
\text { environments, and can be found } \\
\text { throughout the Arabian } \\
\text { Peninsula, and some places in } \\
\text { Africa } \\
\text { (Ibn Sînâ, [14, p. 23], Bedevian } \\
\text { [4, p. 374]). }\end{array}$ & \\
\hline Arundo donax & $\begin{array}{l}\text { Al-Qasab: } \\
\text { It is a tall perennial cane. It has } \\
\text { been widely planted and } \\
\text { naturalized in the mild temperate, } \\
\text { subtropical and tropical regions } \\
\text { of both hemispheres especially in } \\
\text { the Mediterranean } \\
\text { (Bedevian }[4, \text { p. } 84] \text { ). }\end{array}$ & \\
\hline
\end{tabular}


Table 1: Continued.

\begin{tabular}{|c|c|c|}
\hline Scientific name & $\begin{array}{l}\text { Transliterated names (see this list } \\
\text { in al-Karajî }[9, \text { p. 42]) }\end{array}$ & Images \\
\hline $\begin{array}{l}\text { Borage } \\
\text { officinalis }\end{array}$ & $\begin{array}{l}\text { Lisân al-thawr: } \\
\text { It looks like the Ox's tongue. It is } \\
\text { an annual herb in the flowering } \\
\text { plant family Boraginaceae. It is } \\
\text { native to the Mediterranean } \\
\text { region. It remains in the garden } \\
\text { from year to year by self-seeding. } \\
\text { The leaves are edible. The plant is } \\
\text { also commercially cultivated for } \\
\text { borage seed oil extracted from its } \\
\text { seeds } \\
\text { (Ibn Sînâ [14, p. 200], Bedevian } \\
\text { [4, pp. 55-56], and al-Hulu [8, p. } \\
28] \text { ). }\end{array}$ & \\
\hline $\begin{array}{l}\text { Apium } \\
\text { graveolens }\end{array}$ & $\begin{array}{l}\text { Karafs al-mâ': } \\
\text { It is also known as Sium, and } \\
\text { commonly called water parsnips } \\
\text { (Bedevian }[4, \text { p. } 553]) .\end{array}$ & \\
\hline $\begin{array}{l}\text { Silybum } \\
\text { marianum }\end{array}$ & $\begin{array}{l}\text { al-Harshaf: } \\
\text { This species is an annual or } \\
\text { biennial plant of the family } \\
\text { Asteraceae } \\
\text { (Bedevian [4, p. 549]). }\end{array}$ & \\
\hline $\begin{array}{l}\text { Bryonia dioica } \\
\text { Jacq }\end{array}$ & $\begin{array}{l}\text { cInab al-hayyah: } \\
\text { Sometimes this plant is used in } \\
\text { herbalism. In medieval times the } \\
\text { plant was thought to be an } \\
\text { antidote for leprosy. The root can } \\
\text { be } 75 \mathrm{~cm}(30 \text { in) long and } 75 \mathrm{~mm} \\
(3.0 \text { in) thick } \\
\text { (Baxter, v. } 2 \text { [3, entry } 83] \\
\text { Bedevian [4, p. 121]). }\end{array}$ & \\
\hline
\end{tabular}


Table 1: Continued.

\begin{tabular}{|c|c|c|}
\hline $\begin{array}{l}\text { Scientific } \\
\text { name }\end{array}$ & $\begin{array}{l}\text { Transliterated names (see this list } \\
\text { in al-Karajî }[9, \text { p. 42]) }\end{array}$ & Images \\
\hline $\begin{array}{l}\text { Adianthum } \\
\text { capillus } \\
\text { veneris }\end{array}$ & $\begin{array}{l}\text { Bursiyâ wa-shân: } \\
\text { It often may be seen growing on } \\
\text { moist, sheltered and shaded } \\
\text { sandstone or limestone } \\
\text { formations, generally south facing } \\
\text { in the southern hemisphere } \\
\text { (Ibn Sina [14, p. 146], al-Râzî [12, } \\
\text { p. 77], Ibn al-Nafîs [10, p. } \\
\text { 59])**** }\end{array}$ & \\
\hline Urtica dioica & $\begin{array}{l}\text { al-Qarrâs: } \\
\text { in Latin: Camomilla, and in } \\
\text { English: wild Comomile. It is also } \\
\text { known as Nettle, or stinging } \\
\text { Nettle. It is known in Arabic as } \\
\text { Bâbûnij. It is a thorny shrub. It is } \\
\text { an herbaceous perennial flowering } \\
\text { plant } \\
\text { (Ibn Sînâ }[14, \text { pp. 139, 250], } \\
\text { Bedevian }[4, \text { pp. } 64,172,385] \text { ). }\end{array}$ & \\
\hline Iris & $\begin{array}{l}\text { al-Sawsan: } \\
\text { It is a genus of } 260-300 \text { species of } \\
\text { flowering plants. It takes its name } \\
\text { from the Greek word for a } \\
\text { rainbow, which is also the name } \\
\text { for the Greek goddess, Iris. It has } \\
\text { large roots, with stem two to four } \\
\text { feet high. } \\
\text { (Ibn Sinâ [14, p. 220], Bedevian } \\
\text { [4, p. 560], Baxter [3, entry } 82] \text { ). }\end{array}$ & \\
\hline $\begin{array}{l}\text { Melilotus } \\
\text { officinalis }\end{array}$ & $\begin{array}{l}\text { Iklîl al-malik: } \\
\text { This plant is known in some Arab } \\
\text { area as Handaqûq. It is known in } \\
\text { English as Crown Imperial. It } \\
\text { grows in arid areas } \\
\text { (Ibn Sînâ [14, pp. 124-125], } \\
\text { Bedevian [4, pp. 282-283, 593]). }\end{array}$ & \\
\hline
\end{tabular}


Table 1: Continued.

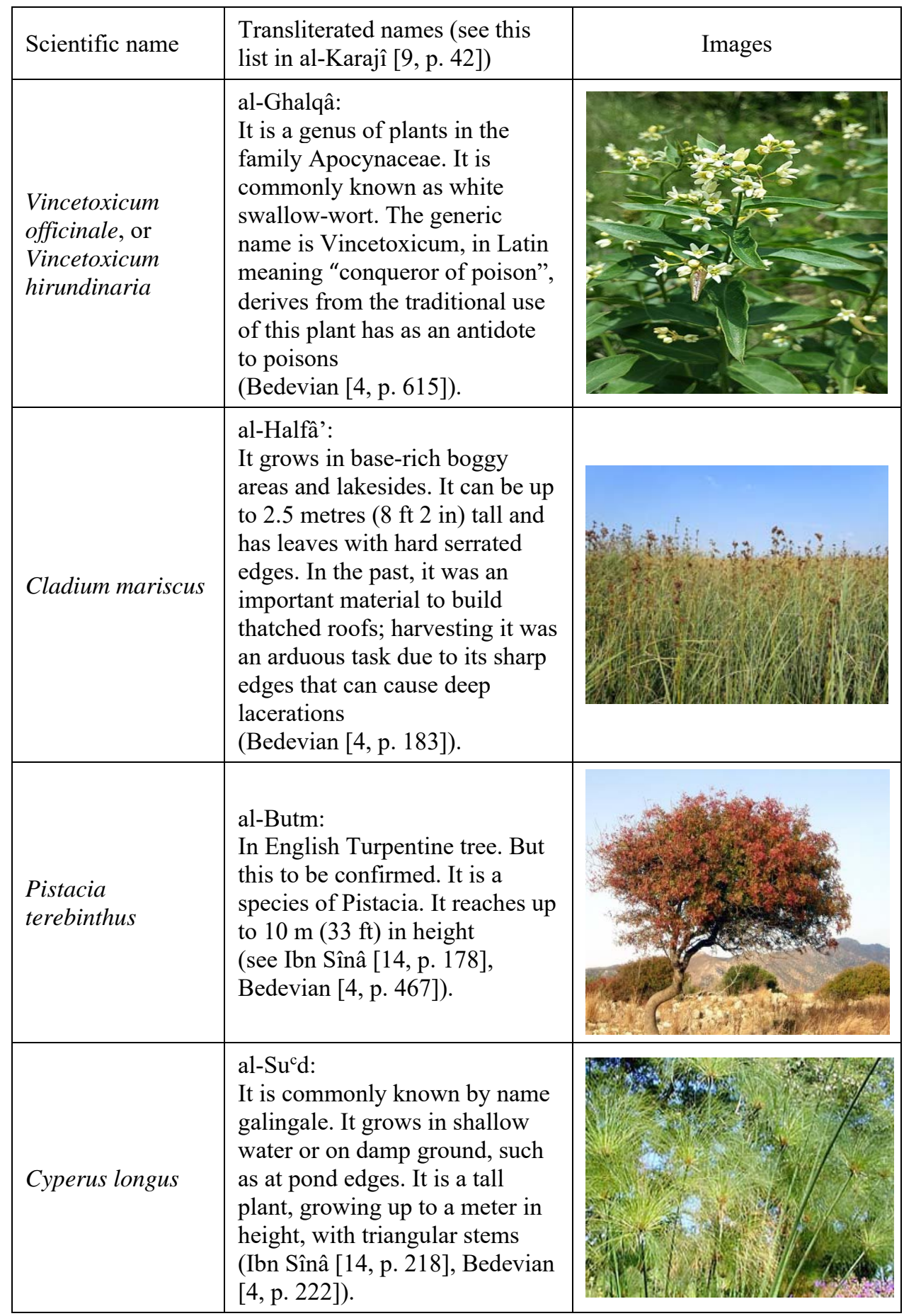


Table 1: Continued.

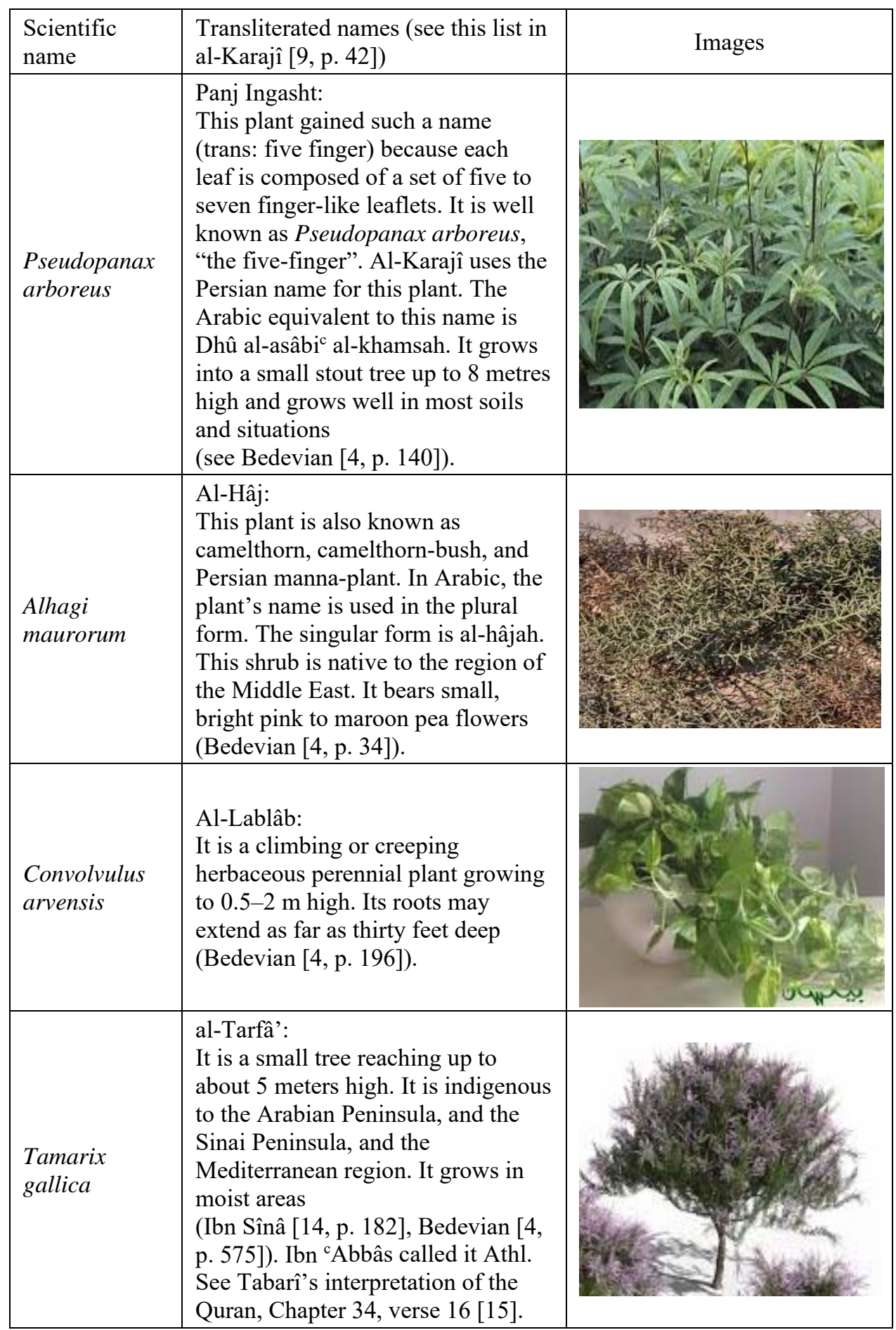


Table 1: Continued.

\begin{tabular}{|c|c|c|}
\hline $\begin{array}{l}\text { Scientific } \\
\text { name }\end{array}$ & $\begin{array}{l}\text { Transliterated names (see this list in } \\
\text { al-Karajî }[9, \text { p. } 42] \text { ) }\end{array}$ & Images \\
\hline $\begin{array}{l}\text { Salix } \\
\text { aegyptiaca }\end{array}$ & $\begin{array}{l}\text { al-Khilâf: } \\
\text { It is known also as Musk Willow, } \\
\text { grows up to } 10 \text { meter in height. It } \\
\text { can grow in heavy clay soil } \\
\text { (Ibn Sînâ [14, p. 273], Bedevian [4, } \\
\text { p. 522]). }\end{array}$ & \\
\hline $\begin{array}{l}\text { Citrullus } \\
\text { colocynthis }\end{array}$ & $\begin{array}{l}\text { al-Hanzal: It has many common } \\
\text { names including colocynth, bitter } \\
\text { apple, bitter cucumber, desert } \\
\text { gourd, or wild gourd, is a desert } \\
\text { viney plant native to the } \\
\text { Mediterranean Basin and Asia. It is } \\
\text { very similar to watermelon vine, but } \\
\text { bears small, hard fruits with a bitter } \\
\text { pulp. It grows in sandy loam, arid } \\
\text { soils, subdesert soils. The roots are } \\
\text { large, fleshy, and perennial, leading } \\
\text { to a high survival rate due to the } \\
\text { long tap root. The vine-like stems } \\
\text { spread in all directions for a few } \\
\text { meters (Ibn Sînâ [14, p. 175], } \\
\text { Bedevian [4, p. 179]). }\end{array}$ & \\
\hline $\begin{array}{l}\text { Arundo } \\
\text { arenaria }\end{array}$ & $\begin{array}{l}\text { al-Qasab al-Daqiq al-Mujawwaf: } \\
\text { This plant has stiff and sharp- } \\
\text { pointed leaves, growing like a rush, } \\
\text { a foot and a half long: the roots both } \\
\text { creep and penetrate deeply into their } \\
\text { sandy beds. No cattle will eat or } \\
\text { touch this vegetable } \\
\text { (Taylor [16, p. 126], Bedevian [4, p. } \\
84] \text { ). }\end{array}$ & \\
\hline Daucus carota & $\begin{array}{l}\text { al-Jazar al-Barrî: } \\
\text { It also known as wild carrot, bird's } \\
\text { nest, bishop's lace, and Queen } \\
\text { Anne's lace. The wild carrot is an } \\
\text { herbaceous, somewhat variable } \\
\text { biennial plant that grows between } \\
30 \text { and } 60 \mathrm{~cm} \\
\text { (Bedevian [4, p. 443]). }\end{array}$ & \\
\hline
\end{tabular}


Table 1: Continued.

\begin{tabular}{|l|l|l|}
\hline $\begin{array}{l}\text { Scientific } \\
\text { name }\end{array}$ & $\begin{array}{l}\text { Transliterated names (see this list in } \\
\text { al-Karajî [9, p. 42]) }\end{array}$ \\
\hline $\begin{array}{l}\text { Moricandia } \\
\text { Arvensis }\end{array}$ & $\begin{array}{l}\text { It is known in English as cabbage } \\
\text { flowered moricandia. It is used as } \\
\text { traditional medicine and in traditional } \\
\text { cooking } \\
\text { (Bedevian [4, p. 402]). }\end{array}$ \\
\hline $\begin{array}{l}\text { Polygonum } \\
\text { aviculare }\end{array}$ & $\begin{array}{l}\text { cAsâ al-râcî: It is an annual found in } \\
\text { arid ground, with white flowers in the } \\
\text { temperate regions. Prostrate } \\
\text { knotweed prefers a habitat with full } \\
\text { sun and a heavy soil. Its roots go far } \\
\text { deep until it blocks underground } \\
\text { conduit sometimes. It is used in the } \\
\text { tradition medicine as it stops the } \\
\text { uterus bleeding (Ibn Sînâ [14, } \\
\text { p. 229], Bedevian [4, p. 475]). }\end{array}$ \\
\hline
\end{tabular}

Although some people might argue that current technology supersedes and makes obsolete these old methods and practices of using and recognizing plants as indicators for detecting underground water, there are certain circumstances when that would not necessarily be the case. In some desert areas, for example, technicians may not be readily available, or they might need electricity and batteries, which might not be available in these areas. Then, too, water detection sensors need technicians who know how to read and interpret a manual about sensors. So, in the absence of this technology and readily available technicians, these old, but effective ways for finding water may still help people who are experiencing drought and famine.

Finally, since the shortage of water at the present time is a worldwide problem, I profoundly believe that any attempt of reconstructing parts from the past may contribute to finding a solution to the global water shortage problem in our present time. The rise of present-day cities, especially in the Middle East, Africa, and other areas often brings about waves of drought and famine. So, these problems require increasingly sophisticated methods of water discovery to supply rapidly growing populations. Doing so will help their land to flourish and enable these populations to attain order in their daily lives.

\section{CONCLUSION}

As one can see, Arabs made major contributions to detecting underground water, constructing water wells and irrigation systems and developing tools and instruments. They coined the term ${ }^{c}$ Ilm al-Riyâfah for the discipline for which they became innovative pioneers. They produced seminal works in the field of hydrology and hydronymy, which can be counted among the oldest texts in these fields. Through their work in mountainous area, valleys, and wastelands they gained enormous experience in detecting the hidden waters. 
They used the color of the mountains to determine where they could dig for water. They realized that the different colors of mountains could help them determine where they could successfully dig for water. In the valleys, where there was arable land, their experience confirmed that plants, rocks, and stones were good signs or indicators of where underground water existed. It is interesting to note that there were experts in detecting the water. These individuals were given profession names such as Qinqin, ${ }^{c}$ Assâs and others. Although these professions did not receive any school-like training for detecting waters, their intuition gave them the reason to believe where water is hidden.

Finally, it is well known that early Arab botanists, pharmacologists and physicians recorded some plants for medical use. In addition to these, Arabs recognized some plants as indicators for underground water. There common factors among these plants were long roots, which went deep into the ground; some plants were thorny, distasteful or even toxic, which helped them to survive despite harsh conditions, drought, and famine.

\section{REFERENCES}

[1] Abattouy, M., Muhammad al-Karaji: Mathmatician Engineer from the Early 11th Century. Muslim Heritage, 4 June 2009. www.muslimheritage.com. Accessed on: Jan. 2020.

[2] Ibn al-A crâbî, Muhammad ibn Ziyâd (150-231/767-845). Kitab al-bi'r, ed. Ramadân 'Abd al-Tawwâb, Dâr al-Macârif: Cairo, 1965.

[3] Baxter, W., British Phaenogamous Batany, J.H. Parker: Oxford, 1835.

[4] Bedevian, A., al-mucjam al-mușawwar li-asmâ' al-nabātāt, Maktabat Madbûlî: Cairo, 1994.

[5] Brauslich, E., The Well in Ancient Arabia, Verlag der Asia Major: Leipzig, 1926.

[6] Forbes, R.J., Studies in Ancient Technology, 2nd ed., E.J. Brill: Leiden, 1993.

[7] Hill, D.R., Islamic Science and Engineering, Edinburgh University Press: Edinburgh, 1993.

[8] al-Hulu, Samîr Ismâcîl. al-Qâmûs al-Jadîd lil-Nabâtât al-Tibbiyah, Dâr al-Manârah: Jeddah, 1999.

[9] Al-Karajî, Muhmmad ibn al-Hasan, Inbât al-miyâh al-khafiyah, ed. Baghdâd ' Abd alMuncim, Machad al-Makhtûtât al-c'Arabiyah: Cairo, 1997.

[10] Ibn al-Nafîs, Alî ibn Abî al-Hazm, Kitâb Mîjis al-Qânûn fî́cilm al-tibb, Matba ${ }^{c}$ Idûkîsh: Kalkata, 1344 a. h.

[11] Niazi, K., Karaji’s discourse on hydrology. Oriens, 44, pp. 44-68, 2016.

[12] al-Râzî, Abu Bakr ibn Zakariyya (d. 313/925). Man lâ yahduruhu al-tabîb, ed. M. Ali Baydûn, Bayrût, n.d.

[13] Selin, H., ed., Encyclopaedia of the History of Science, Technology, and Medicine in non-Western Cultures, 2nd ed., Springler Natuth: Switzerland, 2008.

[14] Ibn Sinâ (Avicenna), Abû cAlî, Kitâb al-qânûn fi al-tibb (The Canon of Medicine), Taybographic Medecea: Rome, 1593.

[15] Tabarî, Muhammad Ibn Jarîr, Tafsîr al-Tabarî (Tabarî's Commentaries on the Quran), Chapter 34, verse 16.

[16] Taylor, J., The Wonders or Trees, Plants, and Shrubs, William Darton: London, 1823.

[17] Watson, A., Agricultural Innovation in the Early Islamic World: The Diffusion of Crops and Farming Techniques, 700-1100, Cambridge University Press: Cambridge, 2008.

[18] Yan-Xi, Z. et al., Portulaca oleracea L.: A review of phytochemistry and pharmacological effects. BioMed Research International, (January) 2015. 